\title{
Xylacanthus laotica (Acanthaceae, Acanthoideae), a new genus and species from Laos
}

\author{
L. V. Averyanov ${ }^{1}$, K. S. Nguyen ${ }^{2}$, T. V. Maisak ${ }^{1}$ \\ ${ }^{1}$ Komarov Botanical Institute RAS, Prof. Popov str., 2, St. Petersburg, 197376, Russia. \\ E-mails:av_leonid@mail.ru; tmaisak@mail.ru \\ ${ }^{2}$ Institute of Ecology and Biological Resources, Vietnam Academy of Science and Technology, 18 Hoang Quoc Viet, \\ Cau Giay, Ha Noi, Vietnam.E-mail:nskhang@gmail.com
}

Keywords: Acanthaceae, karstic flora, Laos, new genus, plant endemism, plant taxonomy, Xylacanthus.

Summary. A new monotype genus Xylacanthus Aver. et K. S. Nguyen with one species, X. laotica Aver. et K. S. Nguyen (Acanthaceae, Acanthoideae, Ruellieae), is described and illustrated. Described genus has arborous living form rather unusual among in Acanthaceae. This small deciduous tree was observed as a main co-dominant of primary deciduous xerophytic karst scrub on extra dry tops of remnant limestone mountains in Pon Xay district of Luang Prabang province in central part of northern Laos. New genus has rather isolated taxonomic position for its floral morphology, xerophytic living form and obligatory deciduous xerophytic character. The distribution of this plant is limited by limestone karstic areas of central part of northern Laos in the limits of Luang Prabang province.

\section{Xylacanthus laotica (Acanthaceae, Acanthoideae) - новый род и вид из Лаоса}

\author{
Л. В. Аверьянов ${ }^{1}$, К. С. Нгуен ${ }^{2}$, Т. В. Майсак ${ }^{1}$ \\ ${ }^{1}$ Ботанический институт им. В. Л. Комарова РАН, ул. Проф. Попова, 2, г. Санкт-Петербург, 197376, Россия \\ ${ }^{2}$ Институт Экологии и Биологических ресурсов, ВАНТ, ул. Хоанг Куок Вьет, 18, район Кай Зяу, г. Ханой, Вьетнам
}

Ключевые слова: карстовые флоры, Лаос, новый род, таксономия растений, эндемизм растений, Acanthaceae, Xylacanthus.

Аннотация. Новый монотипный род Xylacanthus Aver. et K. S. Nguyen с единственным видом, X. laotica Aver. et K. S. Nguyen (Acanthaceae, Acanthoideae, Ruellieae), описан в качестве нового для науки. Описание сопровождается цветными фотографиями и черно-белыми рисунками. Описываемое растение имеет древесную жизненную форму, что крайне редко встречается в семействе Acanthaceae. Открытый вид представляет из себя маленькое листопадное деревцо, являющееся главным доминантом первичной ксерофильной листопадной кустарниковой растительности, покрывающей исключительно сухие карстовые обитания на вершинах известняковых столовых останцев района Пхонсай провинции Луангпхабанг в центральной части северного Лаоса. Новый род занимает изолированное таксономическое положение по морфологии цветка, ксерофитному древесному характеру жизненной формы и облигатной листопадности. Распространение этого растения ограничено карстовыми реликтовыми скальными известняками центральной части северного Лаоса в пределах провинции Луангпхабанг. 


\section{Introduction}

Almost all karstic areas of Laos until now represent botanically unexplored "white spots" with extremely high level of plant endemism. Ancient specific flora of these extra dry formations includes many highly specialized and taxonomically isolated endemic plants, which remains poorly studied (Newman et al., 2007) due to physically difficult access to often hardly accessible mountain summits. Meanwhile, even fragmentary botanical explorations of karstic fields on tops of limestone hills revealed here a series of outstanding botanic discoveries. Among them are semi-woody deciduous Begonia viscosa Aver. et $\mathrm{H}$. Q. Nguyen, Cycas laotica Aver. et al., Eclecticus chungii P. O'Byrne, Paphiopedilum canhii Aver. et O. Gruss, P. rungsuriyanum O. Gruss et al., Peliosanthes hirsuta Aver. et N. Tanaka, P. irinae Aver. et N. Tanaka, Trachycarpus ravenii Aver. et K. S. Nguyen, Tupistra laotica N. Tanaka, Xyloselinum laoticum Pimenov et Aver. and many others. All these plants were exclusively collected on tops of earlier inaccessible karstic mesas (Tanaka et al., 2010; Deng et al., 2011; Averyanov, Nguyen, 2012; Averyanov, 2013; Averyanov et al., 2014a, b, 2015; Gruss et al., 2014; Pimenov et al., 2016; Nguyen et al., 2017). In addition, one more remarkable stenoendemic named here as Xylacanthus laotica was recently discovered in extra dry karstic habitats of central Laos. This plant of very isolated taxonomic position is described and illustrated below.

\section{Materials and methods}

Voucher herbarium specimens and alcoholfixed materials were collected during fieldworks in Laos according to botanical exploration project of U.S.A. National Geographic Society "Assessment of plant diversity in main limestone areas of central Laos" (\#9906-16). Morphological description and measurements were made on the living specimens, as well as herbarium specimens and plant parts fixed in 55-60\% ethanol. In describing quantitative characters, infrequent extreme values, i.e. rarely occurring minimal and maximal values of a variation range were parenthesized respectively before and after a normal variation range. All mentioned specimens presently are stored in Herbarium of National University of Laos (FOF) and in Herbarium of Komarov Botanical Institute of the Russian Academy of Sciences (LE).

\section{Taxonomic treatment}

Xylacanthus Aver. et K. S. Nguyen, gen. nov. Type: X. laotica Aver. et K. S. Nguyen Monotype genus.

\section{Description}

Deciduous monoecious tree to $5 \mathrm{~m}$ tall flowering and fruiting before leaf formation; shoots isophyllous; leaves in terminal rosette, opposite, decussate, pilose; flowers solitary, axillary, sessile; floral bracts 0-2, lanceolate, villose, persistent; calyx 5-lobed, villose, with many cystoliths; corolla dark blue, cylindric, hairy, 5-lobed, lobes rounded, recurved, forming almost actinomorphic limb; stamens 4, didynamous, monadelphous, all fertile, pairwise distally connivent, filaments glandular hairy, at base with many long hairs; anthers basifixed, 2-thecous, thecae with prominent recurved, sterile, acuminate base; connective with many long hairs; ovary erect, narrowly ovoid, setose, 2-locular; style filiform, comose; stigma 2-cleft; capsule ellipsoid, shortly hairy, 6-8-seeded; seeds lenticular, pilose with appressed mucilaginous hairs.

\section{Etymology}

Generic name refers to an arboreous plant habit.

\section{Note}

The discovered plant superficially somewhat resembles species of Strobilanthes Blume, large widespread genus well presented in tropical southeast Asia and in countries of Indochinese Peninsular as well (Benoist, 1935; Pham Hoang Ho, 2000; Deng et al., 2006, 2011; Newman et al., 2007). However, it strikingly differs from all known Strobilanthes species in its unusual arborous plant habit, spurred anthers, filaments and anther connective densely hairy with long white hairs, as well as in many (more than 4)-seeded capsule. Some of these characters, as well as similar pollen grain structure, remind representative of the genus Echinacanthus Nees. However, the only true Echinacanthus species (E. attenuatus Nees) is a lowland slender herb of the Nepal-Darjeeling area, which is totally different in habit from our plant being also geographically separated. It is highly probable that discovered plant represents new undescribed genus endemic for limestone areas of central Laos. Like its expected relatives, it may be placed into subtribe Strobilanthinae (Acanthaceae, subfam. Acanthoideae, tribe Ruellieae) in the family classification proposed by A. Takhtajan (2009). Newly described genus includes one species described below.

X. laotica Aver. et K. S. Nguyen, sp. nov.

Type: "LAOS, Luang Prabang province, Pon Xay district, Houay Man village, Phou Pak 


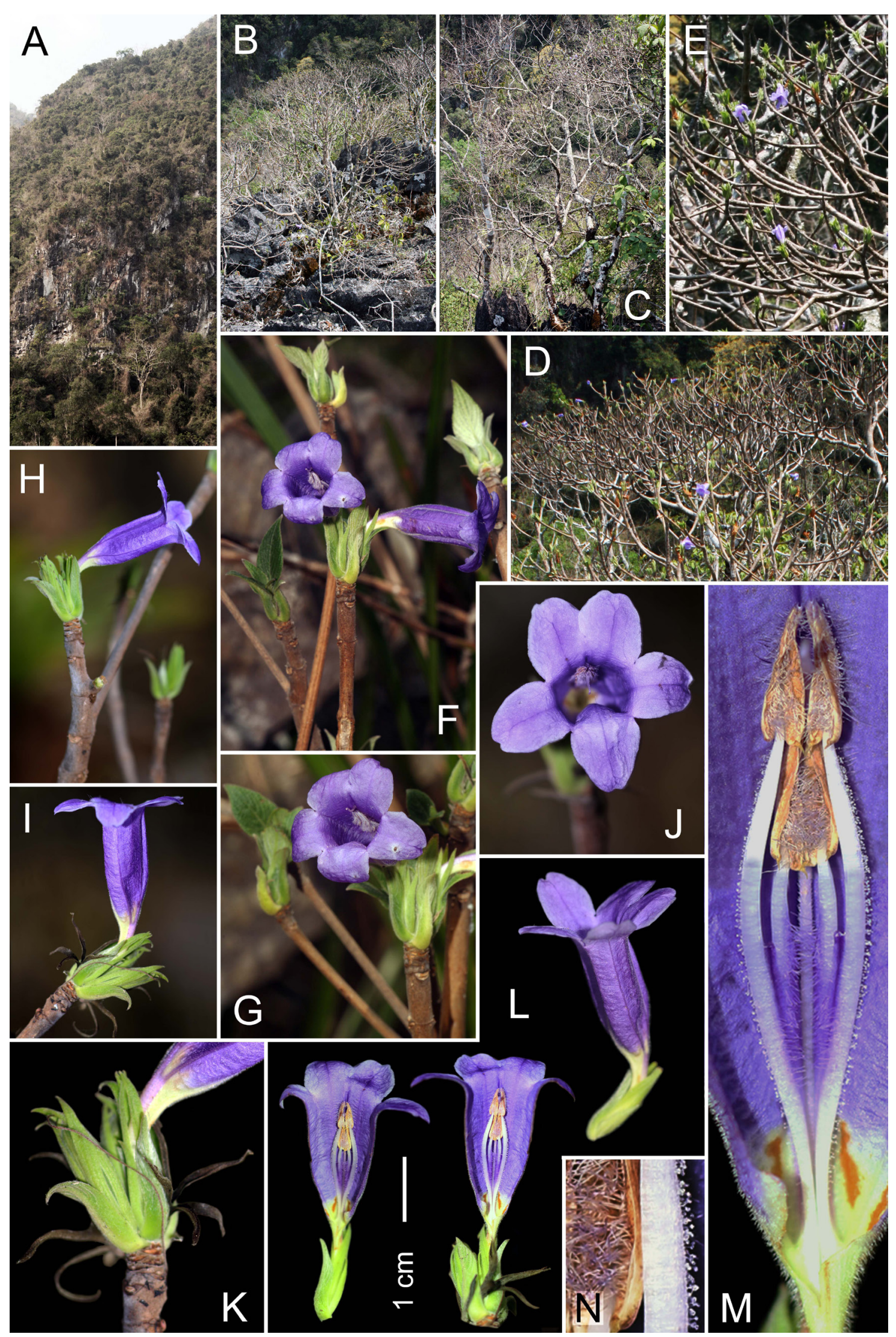

Fig. 1. Xylacanthus laotica. A - Natural habitat of species in Phou Hua Ben Toc Mountain (Luang Prabang province, Pon Xay district, between Houay Man and Nam Bo villages, LA-VN 2130). B - Monodominant deciduous scrub on mountain summit formed by S. arborescens (LA-VN 2130). C - Individual tree of the species on mountain top (LAVN 2130). D, E - Flowering branches of canopy (LA-VN 2130). F-I, K - Flowering and fruiting shoots (Type - LAVN 2050). J, L - Flower, frontal and side view (LA-VN 2157). M - Stamens (LA-VN 2157). N - Hairiness of anther connective and filament (LA-VN 2157). Photos of L. Averyanov and Khang Sinh Nguyen. 


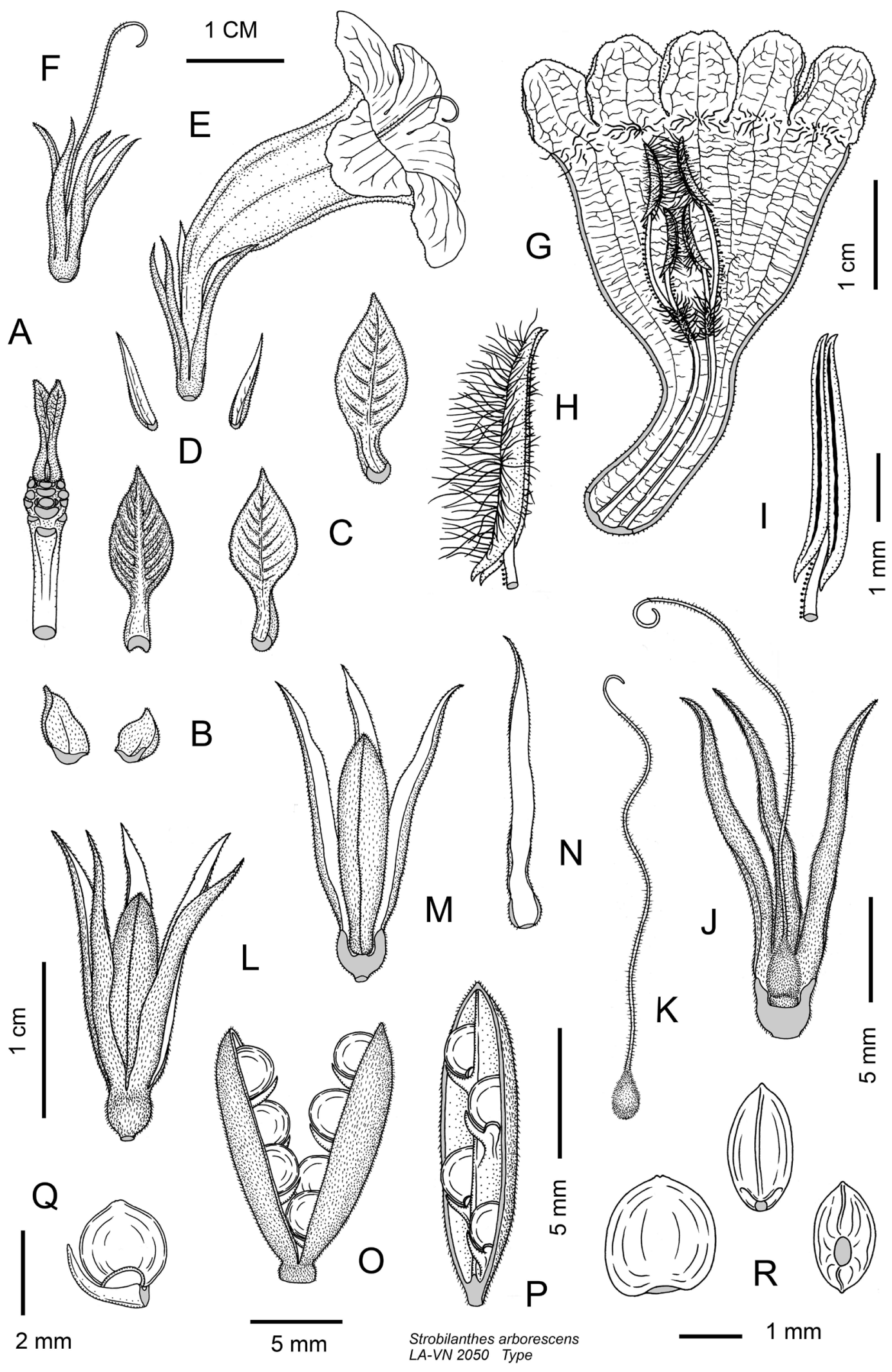

Fig. 2. Xylacanthus laotica. A - Flowering and fruiting stem with removed bud scales, young leaves, floral bracts and flowers. B - Bud scales. C - Young leaves. D. Floral bracts. E - Flower. F - Calyx with young fruit. G - Dissected and flattened perianth tube with removed style. $\mathrm{H}$ - Intact anther, side view. I - Anther with removed hairs, half side view. J - Sagittal section of calyx and gynoecium. K - Ovary and style. L - Calyx and capsule. M - Sagittal section of the calyx and ripe capsule. $\mathrm{N}$ - Individual calyx lobe, adaxial surface. $\mathrm{O}$ - Ripe open capsule, side view. P - Capsule valve with ripening seeds, half side view. Q - Ripening seed with falcate retinaculum. $\mathrm{R}$ - Ripe seed, frontal and side view, and view from the base. All drawn from the type - LA-VN 2050 by L. Averyanov and T. Maisak. 


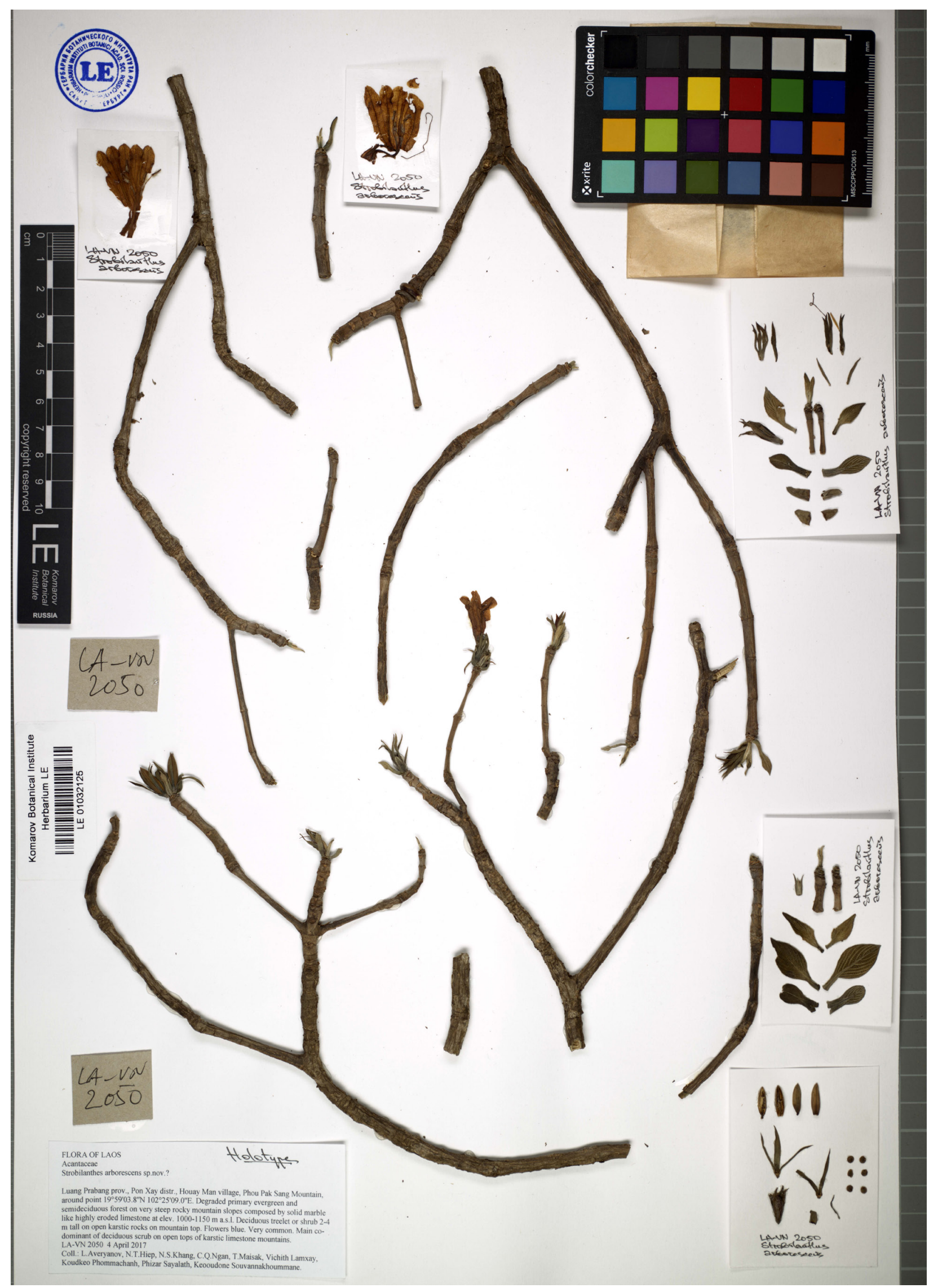

Fig. 3. Xylacanthus laotica. Type specimen - LA-VN 2050, holotype housed at the Herbarium of the Komarov Botanical Institute of the Russian Academy of Sciences (LE). 


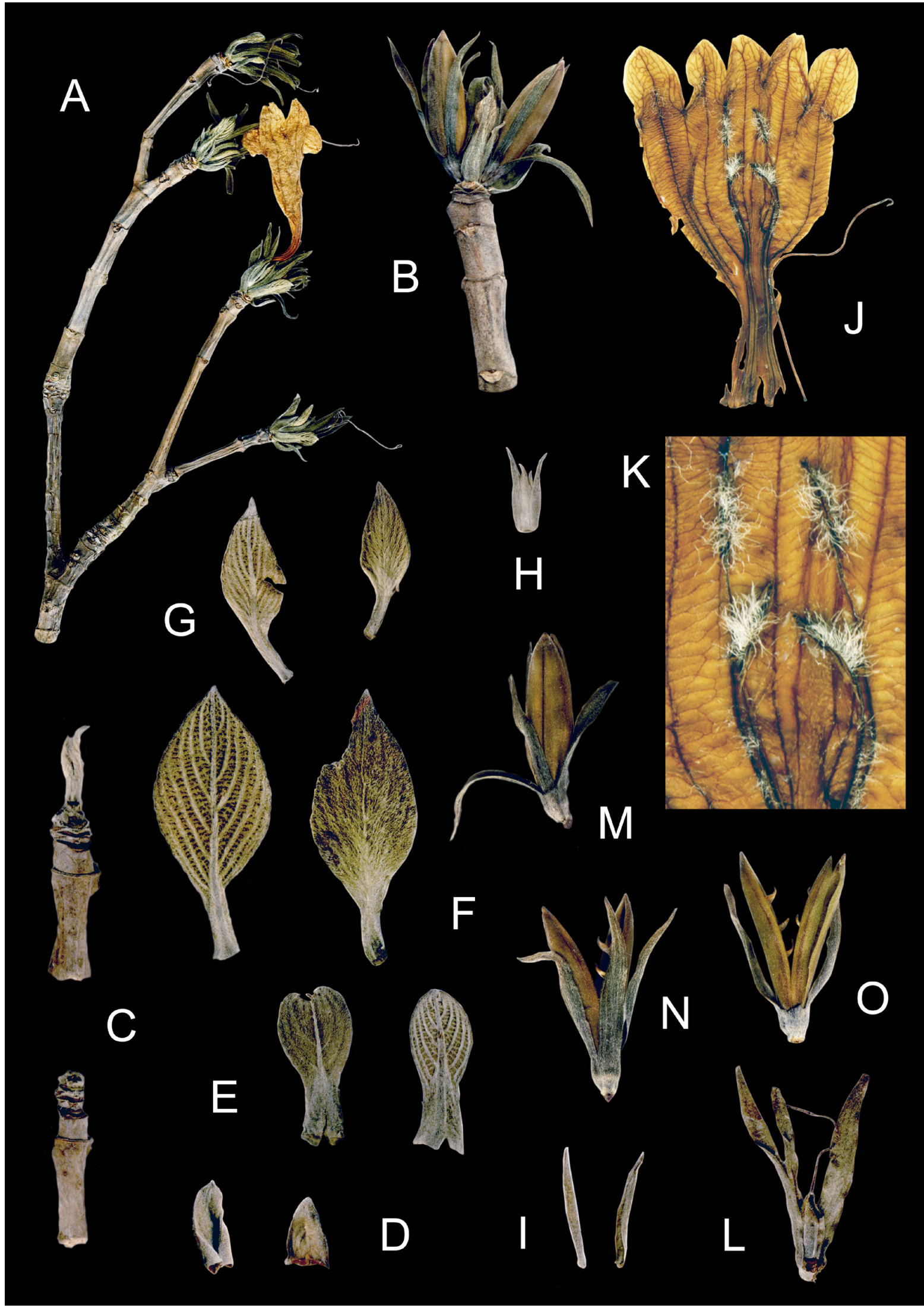

Fig. 4. Xylacanthus laotica. Parts of type specimen. A - Flowering and fruiting branch. B - Branch apex with capsules. $\mathrm{C}-$ Apex of young shoots with bracts, leaves, floral bracts and flowers removed. D. Bud bracts. E-G - Successive leaves. $\mathrm{H}$ - Axillary bud with young leaves, floral bracts and young flowers bud. I - Floral bracts. J - Dissected and flattened perianth tube, adaxial surface. $\mathrm{K}$ - Stamens. L - Calyx and ovary (two calyx lobes removed). M - Calyx and ripening capsule. $\mathrm{N}$ - Calyx and opened capsule. $\mathrm{O}$ - Calyx and opened capsule (three calyx lobes removed). All photos are made from the type - LA-VN 2050 by L. Averyanov. 
Sang Mountain, around point $19^{\circ} 59^{\prime} 03.8^{\prime \prime} \mathrm{N}$, $102^{\circ} 25^{\prime} 09.0^{\prime \prime} \mathrm{E}$, degraded primary evergreen and semideciduous forest on very steep rocky mountain slopes composed by solid marble like highly eroded limestone at elevation $1000-1150 \mathrm{~m}$ a. s. 1 ., deciduous treelet or shrub 2-4 m tall on open karstic rocks on mountain top, flowers blue, very common, main co-dominant of deciduous scrub on open tops of karstic limestone mountains, 4 IV 2017. L. Averyanov, N. T. Hiep, N. S. Khang, C. Q. Ngan, T. Maisak, Vichith Lamxay, Koudkeo Phommachanh, Phizar Sayalath, Keooudone Souvannakhoummane, LA-VN 2050" (holotype - LE 01032125, isotypes FOF, LE).

\section{Description}

Small deciduous hermaphrodite tree to 5 $\mathrm{m}$ tall and stem to $15 \mathrm{~cm}$ in diameter, with broad, oblate, rather dense canopy formed by many branched twigs, flowering and fruiting before (or at early start) of leaf formation. Stem erect, commonly much gnarled, with thick, rough, light-gray, corky bark. Twigs sympodially branching, terete, glabrous or with short scattered scurfy hairs toward the apex, young terminal branches dull olive, pale yellowishgray to dull brownish, smooth, completely leafless during rainless season, (3)4-5(6) $\mathrm{mm}$ in diam., core filled with juicy greenish parenchyma. Buds perulate, ovoid, (4.5)5-7(8) mm long, with 2 thick, rigid, concave, early caducous, ovate, obtuse bud scales, (4)5-7(7.5) mm long. Shoots isophyllous, forming and bearing leaves during rainy season. Leaves at early vegetative stage in dense terminal rosette, opposite, decussate, subsimilar, very rigid, densely white shortly pilose, petiolate. Petiole in young leaves very thick, slightly incurved, shallowly broadly grooved adaxially, (1.5)2-7(8) $\mathrm{mm}$ long, with broad base to $3 \mathrm{~mm}$ wide. Leaf blade of young leaves narrowly ovate to ovate, $(0.5) 1-1.8(2) \mathrm{cm}$ long, (3)4-11(13) mm wide, almost symmetric at the base, slightly decurrent, obtuse to acute, with 5-8 pairs of prominent nerves, entire along margin, adaxially dark green, abaxially light green. Flowers solitary, sessile, arising from leaf axil. Floral bracts $0-2$, narrowly lanceolate to almost linear, (8)10-12(14) mm long, (0.6)0.8-1.2(1.4) $\mathrm{mm}$ wide, conduplicate, acuminate, densely shortly villose on both surfaces, early deciduous, leaving small scars. Calyx light green, fast becoming black, very rigid and fragile, dissected from the base into 5 lanceolate lobes; lobes shallowly cymbiform, acute, abaxially white shortly densely villose, adaxially almost glabrous with many cystoliths, at flowers
(0.8)1-1.5(1.6) cm long, (0.8)1-2(2.2) mm wide, erect, straight, later spreading, irregularly recurved and often somewhat twisted, accrescent in fruit to 2 $\mathrm{cm}$ long. Corolla (2.4)2.6-3(3.2) cm long, widening from the narrow recurved whitish base $6-10 \mathrm{~mm}$ long into dark blue, almost cylindric, obscurely angled, sometime slightly gibbous tube $1.8-2.2 \mathrm{~cm}$ long, (6)8-10(12) mm in diam., abaxially densely, shortly, white hairy, particularly along main veins, inside glabrous, except for a white, long, sparse hairs at the base of corolla lobes. Corolla lobes 5, dark blue, subsimilar, ovate to broadly ovate, (5)5.5-6(6.5) $\mathrm{mm}$ long and broad, rounded, obscurely irregularly crenulate along the margin, bended at the base on $90^{\circ}$, straight or slightly recurved, forming almost actinomorphic perianth limb (1.4)1.6-2.2(2.4) cm in diam. Stamens 4, didynamous, monadelphous, inserted in distal part of narrow part of corolla, all fertile, pairwise distally connivent, 2 longest little shorter than perianth tube; filaments light blue, terete, shorter pair $4.5-5.5 \mathrm{~mm}$ long, longer pair 8-9 mm long; outside with capitate glandular hairs, in basal half with many, long, white hairs; anthers basifixed, 2-thecous, erect, narrowly ellipsoid and slightly falcate, (2.8)3.2-3.8(4.2) long, (0.4)0.5$0.6(0.7) \mathrm{mm}$ wide, both pairs faced to each other, thecae with prominent recurved, sterile, narrowly triangular, acuminate base; connective adaxially and abaxially with many long, flexuose, soft, white hairs. Ovary erect, narrowly ovoid, (1.8)2-2.2(2.4) $\mathrm{mm}$ tall, densely shortly setose, 2-locular; style terete, filiform, flexuose, (2.2)2.4-2.6(2.8) cm long, as long as, or little longer than perianth tube, comose throughout except apical part, stigma 2-cleft with one branch hardly visible and other much longer. Capsule ellipsoid oblong, (9)10-11(12) mm long, (2.8)3(3.2) $\mathrm{mm}$ in diam., densely shortly hairy, 6-8-seeded; retinacula strong, curved, falcate. Seeds almost orbicular, lenticular, flattened, (2)2.22.4(2.6) $\mathrm{mm}$ in diam., $0.6-0.8 \mathrm{~mm}$ thick, pilose with dense, appressed mucilaginous hairs; areole rather small, glabrous (Fig. 1-4).

\section{Etymology}

The species epithet refers to the country of its origin.

\section{Ecology and phenology}

Primary and secondary open semideciduous and deciduous dwarf forests and scrub on extra dry highly eroded karstic fields on summits of remnant table-like hills and mountains composed with solid marble-like rocky limestone at elevations 500-1200 
$\mathrm{m}$ a.s.l. Small deciduous gnarled tree to $5 \mathrm{~m}$ tall and stem to $15 \mathrm{~cm}$ in diameter forming oligo- and monodominant thickets on exposed mossy rocks and rocky cliffs. Locally very common, main codominant of primary scrub on open rocky mountain tops. Flowers and fruits before leaves formation, in March - April at early rainy season.

\section{Distribution}

Northern Laos, Luang Prabang province, Pon Xay district (Houay Man, Nam Bo and Bane Phou Souong villages). Endemic.

\section{Note}

This remarkable plant strikingly differs from almost all known representatives of Acanthaceae family in its arborous living form, xerophytic deciduous character, as well as flowering and fruiting before leaves formation. Oldest observed trees have age at least 2-3 decades and stands in obvious contrast with herbaceous and semi-woody commonly pliestesial Acanthaceae species commonly adopted to humid conditions of shady wet evergreen forests. Like many deciduous xerophytes of extra dry exposed karstic fields, described species has fairly short period of vegetation forming leaves only during rainy season from middle April till September. Tree remains completely leafless during dry rainless winter. Described monotype genus represents typical element of ancient strictly endemic xerophytic limestone flora historically adapted to extra dry summits of karstic limestone formations of northern Laos. This curious, highly specialized flora includes many convergent xerophytic derivates from different families. Unfortunately, it remains still weakly studied. Some other remarkable plants described recently from extra dry karstic limestone fields of northern Laos (Averyanov, Nguyen, 2012; Pimenov et al., 2016) are also similarly woody deciduous xerophytes, e. g. Begonia viscosa (Begoniaceae) and Xyloselinum laoticum (Apiaceae). Like X. laotica, these species also strikingly differ from its herbaceous mesophytic congeners.

\section{Conservation status}

New species was observed as a fairly common plant in several locations in studied area. It often forms oligo- and monodominant thickets on inaccessible summits of table-like limestone formations. Apparently, it also can successfully survive in dry secondary plant communities. Hence IUCN conservation status may be estimated as "Least concern" (LC) despite very limited geographical distribution.

\section{Paratypes}

"Laos, Luang Prabang prov., Pon Xay distr., Houay Man village, Phou Tham Keo Mountain, around point $19^{\circ} 57^{\prime} 44.2^{\prime \prime} \mathrm{N}, 102^{\circ} 25^{\prime} 45.8^{\prime \prime} \mathrm{E}$, degraded primary evergreen and semideciduous forest on very steep rocky mountain slopes composed by solid marble like highly eroded limestone at 500-650 m, deciduous treelet or shrub 2-4 m tall on open karstic rocks on mountain top, flowers blue, very common, main co-dominant of deciduous scrub on open tops of karstic limestone mountains, 4 IV 2017, L. Averyanov et al., LA-VN 2082" (FOF, LE 01041832). "Laos, Luang Prabang prov., Pon Xay distr., between Houay Man and Nam Bo villages, Phou Hua Ben Toc Mountain, around point $19^{\circ} 57^{\prime} 33.1^{\prime \prime N}$, $102^{\circ} 25^{\prime} 25.8^{\prime \prime} \mathrm{E}$, degraded primary evergreen and semideciduous forest on very steep rocky mountain slopes composed by solid marble like highly eroded limestone at 500-650 m, deciduous treelet or shrub 2-4 $\mathrm{m}$ tall on open karstic rocks on mountain top, flowers blue, very common, main co-dominant of deciduous scrub on open tops of karstic limestone mountains, 5 IV 2017, L. Averyanov et al., LAVN 2130" (FOF, LE 01041828, LE 01041829). "Laos, Luang Prabang prov., Pon Xay distr., along the way to Bane Phou Souong village, Pha Hiua Bin Toc Mountain, around point $19^{\circ} 57^{\prime} 37.0^{\prime \prime} \mathrm{N}$, $102^{\circ} 25^{\prime} 03.0^{\prime \prime} \mathrm{E}$, degraded primary evergreen and semideciduous forest on very steep rocky mountain slopes composed by solid marble like highly eroded limestone at $600-850 \mathrm{~m}$, deciduous treelet $2-5 \mathrm{~m}$ tall and to $15 \mathrm{~cm}$ DBH on open rocky mountain top, flowers blue, very common, main co-dominant of primary scrub on open rocky mountain tops, $5 \mathrm{IV}$ 2017, L. Averyanov et al., LA-VN 2157" (FOF, LE 01032126). "Laos, Luang Prabang prov., Pon Xay distr., Nam Bo village, around point $19^{\circ} 57^{\prime} 23.5^{\prime \prime} \mathrm{N}$, $102^{\circ} 26^{\prime} 16.4^{\prime \prime} \mathrm{E}$, degraded primary evergreen and semideciduous forest on very steep rocky mountain slopes composed by solid marble like highly eroded limestone at $650-750 \mathrm{~m}$, deciduous treelet 2-4(5) $\mathrm{m}$ tall and to $15 \mathrm{~cm}$ DBH on open rocky mountain top, flowers blue, very common, main co-dominant of primary scrub on open rocky mountain tops, $6 \mathrm{IV}$ 2017, L. Averyanov et al., LA-VN 2178" (FOF, LE 01041830, LE 01041831).

\section{Acknowledgements}

The results presented in this paper are based on fieldworks that were financially supported in part by research programs of the U.S.A. National Geographic Society "Assessment of plant diversity in 
main limestone areas of central Laos" (\#9906-16) and the Russian Foundation for Basic Research "Plant taxonomy, geography and biology in local floras of eastern Indochina" (15-04-00419A). Field works were organized and managed by National University of Laos (Vientiane) and The Center of
Plant Conservation (Hanoi). Laboratory works were carried out in the framework of institutional research project of the Komarov Botanical Institute of the Russian Academy of Sciences. Authors cordially thanks Dr. John R. I. Wood for fruitful discussion and valuable critical comments.

\section{References}

Averyanov L. V. 2013. New and rare orchids (Orchidaceae) in the flora of Cambodia and Laos. Turczaninowia 16, 4: $26-46$.

Averyanov L. V., Nguyen H. Q. 2012. Eleven new species of Begonia L. (Begoniaceae) from Laos and Vietnam. Turczaninowia 15, 2: 5-32.

Averyanov L. V., Nguyen K. S., Nguyen T. H., Pham T. V., Lorphengsy S. 2014a. Trachycarpus ravenii sp. nov. (Arecaceae, Corypheae) from central Laos. Nord. Journ. Bot. 32, 5: 563-568. DOI: 10.1111/j.1756-1051.2013.00304

Averyanov L. V., Tanaka N., Nguyen K. S., Konstantinov E. L. 2015. A new species and two new records of Ophiopogon and Peliosanthes (Asparagaceae) in the flora of Laos. Taiwania 60, 2: 86-90. DOI: 10.6165/tai.2015.60.86

Averyanov L. V., Nguyen T. H., Nguyen K. S., Pham T. V., Lamxay V., Bounphanmy S., Lorphengsy S., Ke L. P., Lanorsavanh S., Chantthavongsa K. 2014b. Gymnosperms of Laos. Nord. Journ. Bot. 32: 768-805. DOI: 10.1111/ njb.00498

Benoist R. 1935. Acanthacées. In: Flore générale de l'Indo-Chine 4. Eds. P. H. Lecomte, F. Gagnepain. Masson, Paris, 610-772 pp.

Deng Y-F., Hu J-Q., Daniel T. F., Wood J., Wood J. R. I. 2011. Acanthaceae. in Z. Wu and P. H. Raven (eds.), Flora of China, 19. Science Press, Beijing; Missouri Botanical Garden Press, St. Louis, 369-477 pp.

Deng Y-F., Wood J. R. I., Scotland R. W. 2006. New and reassessed species of Strobilanthes (Acanthaceae) in the Flora of China. Botanical Journal of Linnean Socicety 150: 369-390. DOI: https://doi.org/10.1111/j.10958339.2006.00473.x

Gruss O., Rungruang N., Chaisuriyakul Y., Dionisio I. 2014. Paphiopedilum rungsuriyanum eine neue Art aus Nord-Laos a new species discovered in Northern-Laos. Orchideen Journal 2, 1: 2-11.

Newman M., Ketphanh S., Svengsuksa B., Thomas P., Sengdala K., Lamxay V., Armstrong K. 2007. A Checklist of the vascular plants of Lao PDR. Royal Botanic Garden, Edinburgh, 394 pp. URL: http://portals.iucn.org/library/ efiles/documents/2007-014.pdf

Nguyen K. S., Averyanov L. V., Tanaka N., Konstantinov E. L., Maisak T. V., Nguyen H. T. 2017. New taxa of Peliosanthes and Tupistra (Asparagaceae) in the flora of Laos and Vietnam and supplemental data for T. patula. Phytotaxa 312, 2: 199-212.

Pham Hoang Ho. 2000. An illustrated flora of Vietnam. 3. Nha Xuat Ban Tra, Ho Chi Minh, 1020 pp.

Pimenov M. G., Degtjareva G. V., Ostroumova T. A., Samigullin T. H., Averyanov L. V. 2016. Xyloselinum laoticum (Umbelliferae), a new species from Laos, and taxonomic placement of the genus in the light of nrDNA ITS sequence analysis. Phytotaxa 244, 3: 248-262. DOI: http://dx.doi.org/10.11646/phytotaxa.244.3.2

Takhtajan A. 2009. Flowering plants. 2-ed. Springer, New York, 871 pp. DOI: 10.1007/978-1-4020-9609-9

Tanaka N. 2010. A new species of Tupistra (Asparagaceae) from Laos. Jour. Jap. Bot. 85, 2: 69-73. 